\title{
Pengaruh Persepsi Mahasiswa Tentang Penggunaan Media Pembelajaran dan Metode Mengajar Dosen Terhadap Prestasi Mahasiswa Terintegrasi Nilai Karakter
}

\author{
Suripah $^{1}$, Firdaus ${ }^{2}$, Fini Rezy Enabela Novilanti ${ }^{3}$ \\ ${ }^{1,3}$ Pendidikan Matematika, Universitas Islam Riau, Indonesia \\ ${ }^{2}$ Pendidikan Agama Islam, Universitas Islam Riau, Indonesia \\ Jl. KH Nasution No. 113, Perhentian Marpoyan, Pekanbaru, Riau, Indonesia \\ rifah@edu.uir.ac.id
}

\begin{abstract}
Learning achievement is the end result of achieving a process which is still used as a benchmark for success. However, during the implementation of online learning, achievements that are integrated with character values cannot be carried out through direct learning activities. Therefore, research is needed that aims to describe the effect of student perceptions of learning media and teaching methods used by lecturers on student achievement in learning mathematics at FKIP UIR which is integrated with character values. This research is quantitative research that uses a comparative causal method, namely ex post facto. The population in this study were all 6th semester mathematics students of FKIP UIR who took IT-based statistical data analysis courses. The sample of this study amounted to 45 students who were identified through purposive random sampling technique. Collecting data using a questionnaire and data on student test results. The data analysis technique used simple linear regression analysis and simple linear regression analysis using SPSS version 22.0 program. The results showed that based on simple and multiple regression tests, a significant calculated $F$ value of 4.993 was obtained, so it was concluded that student perceptions related to the use of learning media and lecturers' teaching methods had a positive and significant effect on student achievement which was integrated with character values.Therefore, as a lecturer, they must use learning media and apply appropriate learning methods so that students can have a positive influence on student achievement.
\end{abstract}

Keywords: Learning Media, Lecturer Teaching Methods, Student Learning Achievement, Character Value

\begin{abstract}
Abstrak
Prestasi belajar merupakan hasil akhir dari pencapaian sebuah proses yang sampai saat ini masih dijadikan sebagai tolak ukur sebuah keberhasilan. Namun demikian selama diselenggarakannya pembelajaran daring ini prestasi yang terinegrasi dengan nilai-nilai karakter tidak dapat melalui aktivitas pembelajaran secara langsung. Oleh karena itu, diperlukan penelitian yang bertujuan untuk mendeskripsikan pengaruh persepsi mahasiswa tentang media pembelajaran dan metode mengajar yang digunakan dosen terhadap prestasi mahasiswa dalam pembelajaran matematika di FKIP UIR yang terintegrasi dengan nilai karakter. Penelitian ini merupakan penelitian kuantitatif menggunakan metode kausal komparatif yaitu ex post facto. Populasi terdiri dari seluruh mahasiswa semester 6 matematika FKIP UIR yang mengambil mata kuliah analisis data statistik berbasis IT. Sampel untuk penelitian ini terdiri dari 45 siswa yang diidentifikasi melalui teknik purposive random sampling. Pengumpulan data digunakan angket dan data hasil ujian mahasiswa. Teknik analisis data yang digunakan adalah regresi linier sederhana dan analisis regresi linier sederhana menggunakan bantuan program SPSS versi 22.0. Hasil penelitian menunjukkan bahwa berdasarkan uji regresi sederhana maupun ganda, diperoleh nilai $\mathrm{F}$ hitung signifikan sebesar 4,993, sehingga disimpulkan bahwa persepsi mahasiswa terkait penggunaan media pembelajaran dan metode mengajar dosen berpengaruh positif dan signifikan terhadap prestasi mahasiswa yang terintegrasi dengan nilai karakter. Oleh karena itu, sebagai seorang dosen, mestinya menggunakan media pembelajaran dan menerapkan metode pembelajaran yang sesuai agar mahasiswa dapat memberikan pengaruh positif terhadap prestasi belajar mahasiswa.
\end{abstract}

Kata kunci: Media Pembelajaran, Metode Mengajar, Prestasi Mahasiswa, Nilai Karakter

Copyright (c) 2022 Suripah, Firdaus, Fini Rezy Enabela Novilanti

$\triangle$ Corresponding author: Suripah

Email Address: rifah@edu.uir.ac.id (Jl. Kaharuddin Nst No. 113, Perhentian Marpoyan, Riau, Indonesia)

Received 28 December 2021 Accepted 30 January 2022, Published 01 February 2022

\section{PENDAHULUAN}

Prestasi sebagai salah satu simbol kesuksesan seseorang masih menjadi suatu kebanggaan. Oleh 
karena itu, dalam proses pembelajaran terkadang pribadi seseorang lupa akan adanya esensi daripada sebuah prestasi itu sendiri. Bagi sebagian orang, hari ini prestasi masih dinilai sebagai sebuah pencapaian terakhir. Namun demikian prestasi yang membanggakan tanpa adanya dibarengi dengan nilai karakter pada diri seseorang, hasilnya kurang bermakna. Prestasi dapat di kejar dan dicapai dengan belajar keras (Syaparuddin \& Elihami, 2019), minat yang tinggi, perbaikan metode secara inovatif ataupun perbaikan dari fasilitas dan penggunaan media pembelajaran oleh dosen (Pujiastutik, 2019). Namun karakter yang baik, tidaklah mudah untuk dibangun, karakter yang baik membutuhkan proses dan pembiasaan serta kesadaran dalam diri seseorang. Sebagaimana yang diungkapkan Pertiwi \& Marsigit (2017) bahwa karakter yang baik perlu di dorong dan diajarkan oleh seorang guru agar dapat berkembang sebagai bekal siswa untuk masa yang akan datang. Oleh karenanya, tidak mudah menemukan orang yang memiliki prestasi yang tinggi tetapi tetap memiliki nilai karakter baik.

Permasalahan mental atau kebiasaan dan karakter bangsa saat ini menjadi pergunjingan dan sorotan dari masyarakat. Perkembangan teknologi yang semakin canggih yang menjadi salah satu tolak ukur kemajuan justru mendatangkan permasalahan baru (Adawiyah \& Kadir, 2020). Berbagai masalah muncul sebagai akibat aplikasi dan pemanfaatan teknologi canggih yang kurang memperhatikan moral. Permasalahan moral yang terjadi perlu dicarikan solusi supaya tidak berdampak buruk terhadap masa depan generasi bangsa ini. Oleh karenanya peningkatan prestasi mahasiswa secara intelektual mesti dibarengi dengan nilai-nilai karakter (Sugianto \& Ilyas, 2020).

Karakter seseorang tercermin dari sikapnya secara ilmiah dalam mengikuti aktivitas di kelas. Hal ini menjadi bagian yang sangat penting untuk dikembangkan, karena sikap ilmiah merupakan konsep dasar bagi mahasiswa dalam menghargai setiap hasil karya orang lain maupun karya sendiri (Musyarofah et al., 2013). Prestasi yang terintegrasi dengan nilai-nilai karakter pada pembelajaran matematika ditekankan pada pembiasaan bersikap ilmiah, berpikir (Suripah \& Retnawati, 2019), sosial, serta spiritual yang baik. Pembelajaran dengan mengintegrasikan nilai-nilai karakter bertujuan untuk membentuk manusia secara utuh melalui pendekatan pembelajaran yang dilaksanakan secara inovatif dan inspiratif.

Mengingat pentingnya prestasi mahasiswa yang terintegrasi dengan nilai-nilai karakter, pendidikan tinggi sudah selayaknya memberikan dukungan dan bekal untuk persiapan para lulusan yang siap mengahdapi tantangan di era global ini. Semakin luasnya tantangan dan ketatnya saingan di dunia kerja, membutuhkan sosok pribadi yang tidak hanya berprestasi secara akademik. Salah satu nilai lebih yang dibutuhkan adalah sosok pribadi yang memiliki karakter baik, jujur, disiplin, serta bertanggung jawab dalam setiap pekerjaan yang diberikan. Pendidikan karakter yang terintegrasi dalam pembelajaran matematika dinilai sebagai sebuah alternatif cerdas untuk menghasilkan lulusan mahasiswa yang memiliki prestasi tinggi, unggul, berakhlakul karimah, dan menjunjung tinggi nilainilai luhur bangsa. Salah satu aktifitas yang dapat dilakukan untuk membiasakan kegiatan tersebut adalah mengaplikasikan dalam mendesain perangkat pembelajaran (Herlina et al., 2021).

Namun demikian, selama pembelajaran dilaksanakan secara daring mahasiswa memiliki sudut 
pandang yang berbeda tergantung pada persepsi masing-masing mahasiswa. Persepsi merupakan suatu proses saat individu mengatur dan menginterpretasikan kesan sensoris untuk memberikan makna pada lingkungan mereka (Abi Yodha et al., 2019). Perilaku seseorang sering berdasar atas persepsi masing-masing terkait kondisi yang terjadi, bukan pada kenyataan yang sebenarnya (Asri, 2018). Persepsi seseorang bisa negatif ataupun positif tergantung pada apa yang menjadi objek pengamatan dan penilaian dari individu (Ningsih, 2020). Begitu juga persepesi mahasiwa terhadap dosen dalam menyelenggarakan pembelajaran akan berpengaruh terhadap prestasi mahasiswa (You et al., 2016). Berbagai persepsi mahasiswa muncul selama diselenggarakanya pembelajaran daring oleh dosen. Salah satu persepsi adalah terhadap penggunaan media pembelajaran dan metode mengajar dosen pada saat menyelenggarakan perkuliahan.

Dari hasil penelitian sebelumnya oleh (Ferdiana, 2020; Maulana, 2021) telah terbukti bahwa persepsi mahsiswa terhadap dosen dalam penggunaan media pembelajaran berpengaruh terhadap motivasi belajar. Hal ini tentu saja tergantung pada jenis media yang digunakan. Penelitian lain telah mengungkapkan bahwa media pembelajaran online menggunakan Google classroom berpengaruh terhadap minat dan motivasi belajar (Vhalery et al., 2021). Selain itu, persepsi mahasiswa terhadap metode pembelajaran dosen juga berpengaruh terhadap hasil belajar. Disukai atau tidaknya suatu media pembelajaran yang digunakan oleh dosen menjadi salah satu dampak bagi peencapaian hasil. Pernyataan ini didukung oleh hasil kajian sebelunya oleh (Aisyah et al., 2021) bahwa metode pembelajaran yang paling disukai oleh mahasiswa adalah metode diskusi dan diskusi kelas atau interaksi langung (Sutisna, 2016). Lain halnya pembelajaran daring selama dua tahun yang telah berjalan dampak dari adanya Covid 19, tentu metode pembelajaran yang diselenggarakan dosen beragam. Sebagaimana dikuatkan oleh pendapat (Saragih et al., 2020), bahwa selama pembelajaran daring, sebagian besar dosen menggunakan metode belajar yang dapat diterima dan mudah diakses oleh mahasiswa. Dosen tidak banyak berpikir bagaiaman hasil yang dicapai oleh mahasiswa secara berkelanjutan. Terkait dengan pembelajaran berkelanjutan prestasi saja tidaklah cukup. Prestasi perlu diintegrasikan dengan nilai-nilai karakter di dalamnya supaya prestasi yang dimiliki oleh mahasiwa menjadi lebih bermakna. Dari berbagai penelitian sebelumnya yang telah dilakukan, belum terlihat adanya aspek karakter yang diperhatikan. Padahal selama pembelajaran daring, tidak ada indikator nilai karakter yang dapat diamati secara jarak jauh. Atas dasar itu, perlu dilakukan penelitian bagaimana pengaruh persepsi mahasiwa Pendidikan matematika terkait pengunaan media pembelajaran dan metode mengajar dosen terhadap prestasi mahasiswa yang terintegrasi nilai karakter. Berdasarkan tujuan dari penelitian ini, maka hipotesis dari penelitian adalah: (1) Persepsi mahasiswa tentang penggunaan media pembelajaran berpengaruh secara positif terhadap prestasi mahasiwa terintegrasi nilai karakter; (2) persepsi mahasiswa terkait metode mengajar dosen berpengaruh secara positif terhadap prestasi mahasiswa yang terintegrasi nilai karakter; (3) persepsi mahasiswa tentang penggunaan media pembelajaran dan metode mengajar dosen dalam pembelajaran pada mata kuliah analisis data statistik berbasisi IT berpengaruh positif terhadap prestasi belajar 
mahasiswa terintegrasi nilai karakter.

\section{METODE}

Penelitian ini merupakan penelitian kuantitatif menggunakan metode kausal komparatif yaitu expost facto. Expost facto merupakan penelitian yang bertujuan untuk melihat merunut kejadian yang terjadi dan kemudian digunakan kembali untuk mengetahui faktor apa saja yang menjadi penyebab terjadinya peristiwa tersebut. Variabel dalam penelitian ini terdiri dari 3 yaitu variabel terikat $(\mathrm{Y})$ prestasi belajar dan 2 variabel bebas $(\mathrm{X})$ yaitu persepsi penggunaan media pembelajaran $\left(X_{1}\right)$ dan metode pengajaran dosen $\left(X_{2}\right)$. Populasi penelitian ini merupakan mahasiswa pendidikan matematika semester 6 yang terdiri dari dua kelas sebanyak 77 mahasiwa. Teknik sampling yang digunakan dalam penelitian ini menggunkan purposive random sampling. Dalam penelitian ini peneliti mempertimbangkan mahasiswa yang berada pada semester enam dan menempuh mata kuliah analisis data berbasis IT. Satu kelas mengambil mata kuliah pilihan lain, oleh karena salah satu pertimbangn tersebut, maka diambil sampel satu kelas 6A sebanyak 45 mahasiwa.

Instrumen penelitian yang digunakan berupa angket dan data ujian akhir mahasiswa pendidikan matematika UIR. Sebelum dibagikan, angket divalidasi terlebih dahulu sehingga instrumen dapat diketahui kevalidan dan kesahihannya (Suharsimi, 2010). Setelah dikonsultasikan berdasarkan pendapat ahli (judgment experts), angket direvisi berdasarkan masukan dan saran. Setelah divalidasi oleh ahli selanjutnya diujicobakan, untuk dianalisis butir dan reliabilitasnya. Reliabilitas angket diestimasi menggunakan Alpha Cronbach. Instrumen tersebut dapat dipercaya apabila memenuhi kriteria yaitu koefisien Alpha Cronbach lebih besar dari 0 (Siregar, 2010). Analisis untuk validitas dan reliabilitas digunakan bantuan program SPSS versi 22.00. Adapun ringkasan hasil validitas instrumen dari kedua angket disajikan pada Tabel 1 berikut.

Tabel 1. Ringkasan Hasil Validitas Instrumen Angket

\begin{tabular}{|c|c|c|c|c|}
\hline Variabel & Butir Awal & Butir Gugur & No Butir Gugur & Butir Valid \\
\hline X1 & 22 & 4 & $5,8,11,21$ & 18 \\
\hline X2 & 29 & 4 & $5,13,14,25$ & 25 \\
\hline Jumlah & 51 & 8 & & 43 \\
\hline
\end{tabular}

Sumber: Data primer peneliti

Berdasrkan hasil ringkasan pada Tabel 1 dari 22 butir pernyataan instrumen untuk X1, setelah dilakukan ujicoba instrumen ditemukan 4 butir pernyataan yang tidak valid. sehingga butir pernyataan yang valid sebanyak 18 butir digunakan untuk instrumen penelitian. Banyaknya instrumen pada X2 awalnya sebanyak 29 butir. Setelah dilakukan ujicoba dan dianalisis validitasnya, terdapat 4 pernyataan yang tidak valid. Maka dari itu, instrumen yang valid sebanyak 25 butir yang dijadikan untuk instrumen penelitian. Selanjutnya hasil analisis reliabilitas Instrumen selanjutnya dikonsultasikan dengan Tabel $\mathrm{r}$ berikut seperti pada Tabel 2. 
Tabel 2. Interpretasi Nilai r

\begin{tabular}{|l|l|}
\hline Interval Koefisien & Tingkat Hubungan \\
\hline $0,00-0,199$ & Sangat Rendah \\
\hline $0,20-0,399$ & Rendah \\
\hline $0,40-0,599$ & Sedang \\
\hline $0,60-0,799$ & Kuat \\
\hline $0,80-100$ & Sangat kuat \\
\hline
\end{tabular}

Instrumen ujicoba untuk angket persepsi tentang penggunaan media dan metode mengajar masing-masing diperoleh 0,813 dan 0,880. Berdasarkan kriteria tabel untuk interpretasi nilai $\mathrm{r}$ kedua instrumen termasuk reliabel dengan kriteria sangat reliabel. Kategori angket merupakan modifikasi dari skala Likert yang terdiri dari 4 alternatif jawaban yaitu Tidak Pernah (TP), Jarang (JR), Sering (SR), dan Selalu (SL).

Teknik analisis data dalam penelitian ini menggunakan analisis regresi linier sederhana dan analisis regresi linier ganda menggunakan program SPSS versi 22.0. Sebelum melakukan analisis dengan regresi, peneliti terlebih dahulu melakukan uji prasyarat analisis dengan uji linieritas dan uji multikolinearitas. Paradigma penelitian yang dilakukan ditunjukkan pada Gambar 1 di bawah ini:

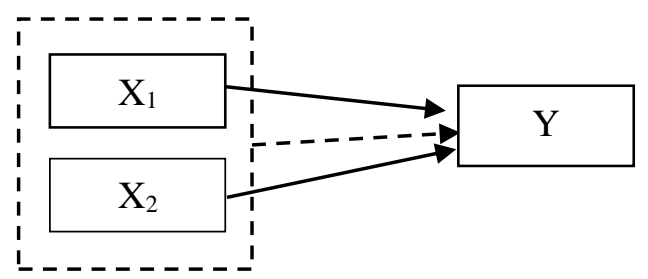

Gambar.1 Paradigma Penelitian

Keterangan:

$X_{1} \quad$ : Persepsi mahasiswa tentang penggunaan media

$X_{2} \quad$ : Persepsi mahasiswa tentang metode mengajar dosen

Y : : Prestasi Belajar Matematika Mahasiswa Terintegrasi Nilai Karakter

$\longrightarrow \quad$ : Pengaruh $X_{1}$ atau $X_{2}$ secara parsial terhadap Y

$\rightarrow \quad$ : Pengaruh $X_{1}$ dan $X_{2}$ secara bersamaan terhadap Y

Adapun kriteri pengambilan keputusan adalah: (1) untuk Hipotesis 1 dan 2, tolak $H_{0}$ jika nilai $\mathrm{T}$ Signifikansi $<0,05$; (2) untuk Hipotesis 3 , tolak $H_{0}$ jika nilai $F$ Signifikansi $<0,05$. Semua pengujian hipotesis digunakan bantuan program SPSS versi 22.0.

\section{HASIL DAN DISKUSI}

\section{Uji Prasyarat Analisis}

Pengujian prasyarat analisis dilakukan sebelum melakukan analisis regresi linier sederhana dan regresi linier ganda. Uji prasyarat meliputi uji linieritas dan multikolinearitas dengan bantuan program SPSS versi 22.0. Hasil uji prasyarat analisis disajikan sebagai berikut. 
Pertama adalah uji linieritas. Uji linieritas dilakukan untuk mengetahui ada hubungan atau tidaknya antar variabel bebas dengan variabel terikat, dan linier atau tidak. Rangkuman hasil uji linieritas dengan bantuan program SPSS versi 22.0 ditunjukkan pada Tabel 3 di bawah ini:

Tabel 3. Ringkasan Hasil Uji Linieritas

\begin{tabular}{|c|c|c|c|}
\hline Variabel & F_Hitung & Nilai Sig & Keterangan \\
\hline$X_{1} Y$ & 1,487 & 0,18 & Linier \\
\hline$X_{2} Y$ & 1,775 & 0,097 & Linier \\
\hline
\end{tabular}

Dari hasil output uji linieritas Tabel 3 menunjukkan bahwa variabel $X_{1}$ (penggunaan media pembelajaran) sebesar $0,18 \geq 0,05$ dan untuk variabel $X_{2}$ (metode mengajar dosen) sebesar 0,097 $\geq$ 0,05. Dari sini dapat disimpulkan bahwa kedua variabel tersebut signifikan. Pengaruh persepsi mahasiswa terkait penggunaan media pembelajaran $\left(X_{1}\right)$, dan pengaruh persepsi mahasiswa terkait metode mengajar dosen $\left(X_{2}\right)$ terhadap prestasi mahasiswa terintegrasi nilai karakter $(Y)$ bersifat linier.

Kedua adalah uji multikoliniearitas, dilakukan untuk mengetahui apakah terdapat hubungan linier antar variabel $\mathrm{X}_{1}$ dan $\mathrm{X}_{2}$. Rangkuman hasil uji multikolinearitas dengan bantuan program SPSS versi 22.0 ditunjukkan pada Tabel 4 di bawah ini.

Tabel 4 Ringkasan Hasil Uji Multokolinieritas

\begin{tabular}{|c|c|c|c|c|c|c|c|}
\hline \multirow{2}{*}{ Model } & \multicolumn{2}{|c|}{$\begin{array}{c}\text { Unstandardized } \\
\text { Coefficients }\end{array}$} & \multirow{2}{*}{$\begin{array}{c}\begin{array}{c}\text { Standardized } \\
\text { Coefficients }\end{array} \\
\text { Beta } \\
\end{array}$} & \multirow{2}{*}{$\mathbf{T}$} & \multirow{2}{*}{ Sig. } & \multicolumn{2}{|c|}{$\begin{array}{c}\text { Collinearity } \\
\text { Statistics }\end{array}$} \\
\hline & B & $\begin{array}{l}\text { Std. } \\
\text { Error }\end{array}$ & & & & Tolerance & VIF \\
\hline 1 (Constant) & 49.677 & 9.378 & & 5.297 & .000 & & \\
\hline Penggunaan_Media & .410 & .183 & .314 & 2.236 & .031 & .974 & 1.027 \\
\hline Metode_Mengajar & .151 & .082 & .259 & 1.843 & .072 & .974 & 1.027 \\
\hline
\end{tabular}

a. Dependent Variable: Prestasi_Matematika

Data dianggap bebas multikolinearitas jika nilai VIF kurang dari 10,00. Sebaliknya, ketika nilai VIF sama dengan atau lebih besar dari 10,00, data tersebut memiliki multikolinearitas. Berdasarkan output uji multikolinearitas diperoleh nilai VIF sebesar 1,027, sehingga dapat disimpulkan bahwa tidak terdapat multikolinearitas antara variabel $X_{1}$ dan $X_{2}$. Hal ini berarti bahwa tidak terjadi korelasi antar variabel bebas, sehingga model regresi dapat diandalkan.

\section{Uji Hipotesis}

Hipotesis pertama menyatakan bahwa persepsi mahasiswa terkait penggunaan media pembelajaran berpengaruh secara positif terhadap prestasi mahasiwa terintegrasi nilai karakter. Hasil pengujian hipotesis pertama menggunakan program SPSS versi 22.0 ditunjukkan pada Tabel 5 di bawah ini. 
Tabel. 5. Hasil Uji Hipotesis Pertama (Coefficientsa)

\begin{tabular}{|c|c|c|c|c|c|c|}
\hline \multirow{2}{*}{\multicolumn{2}{|c|}{ Model }} & \multicolumn{2}{|c|}{$\begin{array}{l}\text { Unstandardized } \\
\text { Coefficients }\end{array}$} & \multirow{2}{*}{$\begin{array}{c}\text { Standardized } \\
\text { Coefficients } \\
\text { Beta }\end{array}$} & \multirow[b]{2}{*}{$\mathrm{T}$} & \multirow[b]{2}{*}{ Sig. } \\
\hline & & B & $\begin{array}{l}\text { Std. } \\
\text { Error }\end{array}$ & & & \\
\hline \multirow[t]{2}{*}{1} & (Constant) & 58.034 & 8.434 & & 6.881 & .000 \\
\hline & Penggunaan_Media & .464 & .186 & .356 & 2.498 & .016 \\
\hline
\end{tabular}

Berdasarkan Tabel 5, pengujian hipotesis menyatakan bahwa persepsi mahasiswa tentang penggunaan media memiliki dampak positif terhadap prestasi mahasiswa terintegrasi nilai karakter. Uji signifikansi dengan uji-t menghasilkan t-hitung sebesar 2,498, sehingga dapat diasumsikan bahwa persepsi mahasiswa terhadap penggunaan media pembelajaran berpengaruh positif terhadap prestasi belajar terintegrasi nilai karakter. Nilai t-tabel dengan tingkat kepercayaan 5\% adalah 2,018. Artinya t-hitung lebih besar dari t-tabel $(2,498>2,018)$, sehingga persepsi mahasiswa terhadap penggunan nnedia pembelajaran memiliki pengaruh positif dan signifikan terhadap keberhasilan belajar. Dengan demikian dapat dikatakan bahwa semakin baik persepsi siswa terhadap penggunaan media maka semakin baik pula prestasi mahasiswa dalam pembelajaran matematika di FKIP UIR yang terintegrasi dengan nilai-nilai karakter yang dicapai.

Hasil penelitian ini sejalan dengan penelitian(Setyono, 2017) yang menyatakan bahwa adanya pengaruh positif kompetensi guru dan struktur pembelajaran guru terhadap pengajaran guru. Selain itu, penggunaan perangkat pembelajaran oleh guru dapat secara efektif meningkatkan motivasi dan kinerja mahasiswa (Kurniawati, 2018) serta hasil pembelajaran (Nuriansyah, 2020). Hasil penelitian ini juga relevan dengan teori Purwanto (2010) bahwa hasil belajar dipengaruhi oleh beberapa faktor, antara lain penggunaan media pembelajaran. Persepsi positif terhadap media pembelajaran oleh mahasiswa dapat berdampak baik pada prestasi belajar mahasiswa. Semakin baik persepsi mahasiswa terhadap penggunaan media pembelajaran, maka semakin baik pula hasil belajar yang dicapai. Ketika mahasiswa menilai penggunaan media dosen secara positif, mahasiswa termotivasi untuk lebih meningkatkan pemahaman dan keterampilan teknologi secara teknis sehingga lebih mensyukuri penggunaan media dan kemudahan yang didapatkan. Oleh karena itu, penggunaan media pembelajaran oleh dosen menjadi penting karena berpengaruh positif terhadap prestasi yang terintegrasi dengan nilai karakter (Ekayani, 2017).

Pengujian terhadap hipotesis kedua yang menyatakan bahwa persepsi mahasiswa terkait metode mengajar dosen berpengaruh secara positif terhadap prestasi mahasiswa yang terintegrasi nilai karakter. Hasil uji hipotesis kedua yang dibantu dengan program SPSS versi 22.0 dapat dilihat pada Tabel 6 berikut. 
Tabel 6. Uji Hipotesis Kedua

Coefficientsa

\begin{tabular}{|c|c|c|c|c|c|}
\hline \multirow[b]{2}{*}{ Model } & \multicolumn{2}{|c|}{$\begin{array}{l}\text { Unstandardized } \\
\text { Coefficients }\end{array}$} & \multirow{2}{*}{$\begin{array}{c}\text { Standardized } \\
\text { Coefficients } \\
\text { Beta }\end{array}$} & \multirow[b]{2}{*}{$\mathrm{T}$} & \multirow[b]{2}{*}{ Sig. } \\
\hline & B & $\begin{array}{l}\text { Std. } \\
\text { Error }\end{array}$ & & & \\
\hline $\begin{array}{ll}1 & \text { (Constant })\end{array}$ & 66.096 & 6.098 & & 10.838 & .000 \\
\hline Metode_Mengajar & .180 & .084 & .310 & 2.136 & .038 \\
\hline
\end{tabular}

a. Dependent Variable: Prestasi_Matematika

Dari Tabel 6 hipotesis persepsi mahasiswa terkait metode pembelajaran berpengaruh positif terhadap prestasi belajar terintegrasi nilai karakter. Tes signifikansi menggunakan uji-t diperoleh thitung adalah 2,136, sehingga dapat diasumsikan bahwa hipotesis kedua terbukti. Nilai t-tabel dengan tingkat kepercayaan 5\% adalah 2,018. Artinya angka t hitung lebih besar dari t tabel $(2,136>2,018)$, sehingga persepsi mahasiswa terkait metode mengajar dosen berpengaruh secara positif dan signifikan terhadap prestasi belajar mahasiswa terintegrasi nilai karakter. Dengan demikian dapat dikatakan bahwa semakin baik persepsi mahasiswa terkait metode mengajar dosen pada mata kuliah analisis data statistik berbasis IT maka prestasi mahasiswa Pendidikan matematika FKIP UIR terintegrasi nilai karakter akan semakin baik pula.

Hasil penelitian ini sejalan dengan penelitian (Ibadi, 2013) yang menunjukkan adanya pengaruh positif dan signifikan terhadap persepsi variasi metode mengajar bagi dosen mata kuliah teknik mesin. Hasil penelitian ini juga dikuatkan oleh pandangan Ngalim Purwanto bahwa beberapa faktor mempengaruhi prestasi belajar, termasuk metode mengajar. Apabila persepsi mahasiwa cenderung positif terhadap metode mengajar yang diselenggarakan oleh dosen, maka prestasi mahasiswa pendidikan matematika FKIP UIR yang terintegrasi dengan nilai karakter pun akan semakin baik. Begitu pula mengenai penilaian karakter, (Musyarofah et al., 2013; Ulya \& Hayati, 2020) menekankan bahwa kebiasaan penilaian karakter positif dalam pembelajaran perlu lebih ditingkatkan. Persepsi mahasiswa terhadap metode pengajaran pada mata kuliah analisis data IT akan memotivasi mahasiswa untuk lebih memilih mata kuliah analisis data statistik IT agar mahasiswa serius dalam belajar secara online dan tatap muka di kampus.

Uji hipotesis ketiga yaitu persepsi mahasiswa tentang penggunaan media pembelajaran dan metode mengajar dosen dalam pembelajaran pada mata kuliah analisis data statistik berbasisi IT berpengaruh positif terhadap prestasi belajar mahasiswa terintegrasi nilai karakter. Rangkuman hasil pengujian hipotesis ketiga dengan bantuan program SPSS Versi 22.0 ditunjukkan pada Tabel 7 berikut. 
Tabel 7. Ringkasan Hasil Output Uji Hipotesis Ketiga

\begin{tabular}{|l|r|c|l|l|l|l|l|}
\hline Variabel & $\boldsymbol{X}_{\mathbf{1}}$ & $\boldsymbol{X}_{\mathbf{2}}$ & Konstanta & $\boldsymbol{R}_{\boldsymbol{y}(\mathbf{1}, \mathbf{2})}$ & $\boldsymbol{R}_{\boldsymbol{y}(\mathbf{1}, \mathbf{2})}^{\mathbf{2}}$ & $\boldsymbol{F}_{\text {hitung }}$ & $\boldsymbol{F}_{\text {tabel }}$ \\
\hline Koefisien & 0,410 & 0,151 & 49,677 & 0,438 & 0.192 & 4,993 & 3,22 \\
\hline
\end{tabular}

*) Variabel Terikat: Prestasi Belajar Matematika

Dari ringkasan hasil Uji Hipotesis ketiga pada Tabel 7, berdasarkan hasil uji F menunjukkan bahwa nilai F hitung adalah 4,993. Dengan kata lain hipotesis diterima, yaitu persepsi Mahasiwa terkait metode mengajar dosen bcrpengaruh secara positif terhadap prcstasi belajar matematika. Apabila dibandingkan dengan F-tabel sebesar 3,22 dengan tingkat kepercayaan 05\%, maka 4,993 > 3,22 ( $\left.F_{\text {hitung }}>F_{\text {tabel }}\right)$, sehingga persepsi mahasiswa terkait penggunaan media pembelajaran dan metode mengajar dosen pada mata kuliah analisis data statistik berbasis IT berpengaruh positif dan signifikan terhadap pencapaian prstasi terintegrasi nilai karakter.

Hasil penelitian ini relevan dengan hasil penelitian (Erin \& Maharani, 2018) bahwa persepsi mahasiswa tentang pembelajaran online yang diselenggarakan oleh dosen terhadap prestasi belajar berpengaruh positif dan signifikan. Hasil penelitian ini juga relevan dengan hasil (Irawan \& Suryo, 2017) dan (Suryani \& Andriani, 2020) bahwa prestasi belajar seseorang dipengaruhi oleh penggunaan media dan metode mengajar dosen. Media dan metode mengajar secara bersamaan dengan mengintegrasikan nilai karakter di dalamanya akan memperkuat prestasi tidak hanya sekedar nilai yang yang diperoleh oleh mahasiwa (Sugianto \& Ilyas, 2020). Oleh karena itu, semakin baik penggunaan media dan metode mengajar dosen, maka prestasi mahasiswa pendidikan matematika FKIP UIR yang terintegrasi dengan nilai karakter yang diperoleh juga akan semakin baik. Hal menjadi salah satu indikator bahwa mahasiswa yang memiliki persepsi positif terhadap penggunaan media dan metode mengajar dosen menjadi lebih dapat mengahargai setiap materi perkuliahan dan lebih bersemangat dalam mengikuti perkuliahan yang diselenggarakan oleh dosen baik perkulihan, secara daring, menggunakan web (Susanti \& Suripah, 2021) maupun dalam pelaksanaan tatap muka secara langsung di kelas menggunakan bantuan aplikasi, software, bisa berupa media interktif lainnya seperti lectora inspire, video dan lainya (Akbarini et al., 2018; Wisada \& Sudarma, 2019; Novilanti \& Suripah, 2021). Selain itu, teknologi juga dapat menghadirkan suasana kelas yang sesuia dengan kebutuhan dan tuntutan zaman.

Dengan demikian dapat dikatakan bahwa persepsi mahasiswa terkait penggunaan media pembelajaran dan mctode mengajar dosen yang baik akan memberikan dampak yang baik terhadap prestasi mahasiswa pendidikan matematika FKIP UIR yang terintegrasi karakter. Begitu juga sebaliknya, apabila persepsi mahasiswa terhadap duak komponen tersebut tidak baik, maka akan berdampak kurang baik terhadap pencapaian prestasi mahasiswa pendidikan matematika FKIP UIR yang terintegrasi nilai karakter. 


\section{KESIMPULAN}

Berdasarkan hasil penelitian yang telah dilakukan maka dapat disimpulkan bahwa persepsi mahasiwa tentang penggunaan media pembelajaran dan imetode mengajar dosen masing-masing memiliki pengaruh positif dan signifikan terhadap pretasi mahasiswa pendidikan matematika FKIP UIR yang terintegrasi nilai karakter. Hal ini berarti dalam proses pembelajaran akan lebih baik jika seorang dosen dapat menggunakan media pembelajaran pada saat proses pembelajaran supaya dapat memberikan pengaruh yang baik pada prestasi belajar mahasiswa.

Merujuk dari hasil penelitian, terdapat beberapa hal yang perlu disarankan. Pertama, bagi para dosen supaya dapat mengembangkan penelitian ini lebih berfokus untuk meninjau faktor-fakor lain yang dapat mempengaruhi prestasi mahasiwa khususnya selama masa pembelajaran daring ini. Kedua, bagi para peneliti senjutnya supaya dapat mengembangkan penilaian karakter dengan lebih spesifik lagi kaitannya dengan penelitian yang berkelanjutan. Ketiga, bagi para dosen supaya dapat menggunakan media pembelajaran yang lebih bervariasi sebagaiamana terbukti berpengaruh positif terhadap prestasi mahasiswa.

\section{UCAPAN TERIMA KASIH}

Terima kasih kepada DPPM Universitas Islam Riau dan Program Studi Pendidikan Matematika yang telah membantu pendanaan penelitian melalui program penelitian internal. Terima kasih kepada mahasiswa yang telah bersedia berpartisipasi dalam mengisi kuesioner penelitian dan kepada berbagai pihak yang telah berkontribusi dalam penyelesaian penelitian ini yang tidak dapat disebutkan satu persatu.

\section{REFERENSI}

Abi Yodha, S., Abidin, Z., \& Adi, E. P. (2019). Persepsi mahasiswa terhadap pelaksanaan e-learning dalam mata kuliah manajemen sistem informasi mahasiswa Jurusan Teknologi Pendidikan Universitas Negeri Malang. Jurnal Kajian Teknologi Pendidikan, 2(3), 181-187. https://doi.org/10.17977/um038v2i32019p181

Adawiyah, D. P. R., \& Kadir, N. (2020). Analisis Peran Media dalam Upaya Pencegahan Penyebaran Virus Corona (Covid-19) di Indonesia. Jurnal Mediakita: Jurnal Komunikasi Dan Penyiaran Islam, 4(1). https://doi.org/10.30762/mediakita.v4i1.2444

Aisyah, S., Musyaddad, K., \& Safita, R. (2021). Persepsi Mahasiswa terhadap Metode Pembelajaran yang Diterapkan oleh Dosen. UIN Sulthan Thaha Saifuddin Jambi. http://repository.uinjambi.ac.id/id/eprint/8476

Akbarini, N. R., Murtini, W., \& Rahmanto, A. N. (2018). The effect of Lectora inspire-based interactive learning media in vocational high school. Jurnal Pendidikan Vokasi, 8(1), 78-87. https://doi.org/10.21831/jpv.v8i1.17970

Asri, Y. N. (2018). Hubungan Persepsi Mahasiswa pada Kinerja Dosen terhadap Tingkat Kelulusan 
Mahasiswa. Al-Tanzim: Jurnal Manajemen Pendidikan Islam, 2(2), 129-136. https://doi.org/10.33650/al-tanzim.v2i2.394

Ekayani, P. (2017). Pentingnya penggunaan media pembelajaran untuk meningkatkan prestasi belajar siswa. Jurnal Fakultas Ilmu Pendidikan Universitas Pendidikan Ganesha Singaraja, 2(1), 1-11.

Erin, E., \& Maharani, A. (2018). Persepsi Mahasiswa Pendidikan Matematika Terhadap Perkuliahan Online. Mosharafa: Jurnal Pendidikan Matematika, 7(3), 337-344. https://doi.org/10.31980/mosharafa.v7i3.39

Ferdiana, S. (2020). Persepsi Mahasiswa tentang Penggunaan Media Daring pada Program Studi S1 Ilmu Gizi Sekolah Tinggi Ilmu Kesehatan Surabaya selama Masa Pandemi Corona Virus Disease (COVID-19). Indonesian Journal of Science Learning, 1(1), 5-12. https://doi.org/10.15642/ijsl.v2i2

Herlina, S., Suripah, S., Istikomah, E., Yolanda, F., Rezeki, S., Amelia, S., \& Widiati, I. (2021). Pelatihan Desain LKPD dalam Pembelajaran Matematika Terintegrasi Karakter Positif Bagi Guru-Guru Sekolah Menengah/Madrasah di Pekanbaru. Community Education Engagement Journal, 2(2), 27-34. https://doi.org/10.25299/ceej.v2i2.6561

Ibadi, M. (2013). Pengaruh Persepsi Mahasiswa Tentang Variasi Mengajar Dosen Terhadap Hasil Belajar Dalam Mata Kuliah Teknik Permesinan. Jurnal Pendidikan Teknik Mesin, 9(1). https://journal.unnes.ac.id/nju/index.php/JPTM/article/view/216

Irawan, E., \& Suryo, T. (2017). Implikasi multimedia interaktif berbasis flash terhadap motivasi dan prestasi belajar matematika. Beta: Jurnal Tadris Matematika, 10(1), 33-50. https://doi.org/10.25273/doubleclick.v1i2.1540

Kurniawati, I. D. (2018). Media pembelajaran berbasis multimedia interaktif untuk meningkatkan Pemahaman konsep mahasiswa. DoubleClick: Journal of Computer and Information Technology, I(2), 68-75. https://doi.org/10.25273/doubleclick.v1i2.1540

Maulana, H. A. (2021). Persepsi Mahasiswa terhadap Pembelajaran Daring di Pendidikan Tinggi Vokasi: Studi Perbandingan antara Penggunaan Google Classroom dan Zoom Meeting. Edukatif: Jurnal Ilmu Pendidikan, 3(1), 188-195. https://doi.org/10.31004/edukatif.v3i1.259

Musyarofah, Hindarto, N., \& Mosik. (2013). Pendidikan Karakter Terintegrasi dalam Pembelajaran IPA Guna Menumbuhkan Kebiasaan Bersikap Ilmiah. UPEJ Unnes Physics Education Journal, 2(2). https://doi.org/10.15294/upej.v2i2.2665

Ningsih, S. (2020). Persepsi Mahasiswa Terhadap Pembelajaran Daring Pada Masa Pandemi Covid19. JINOTEP (Jurnal Inovasi Dan Teknologi Pembelajaran): Kajian Dan Riset Dalam Teknologi Pembelajaran, 7(2), 124-132. https://doi.org/10.17977/um031v7i22020p124

Novilanti, F. R. E., \& Suripah, S. (2021). Alternatif Pembelajaran Geometri Berbantuan Software GeoGebra di Masa Pandemi Covid-19. Jurnal Cendekia: Jurnal Pendidikan Matematika, 5(1), 357-367. https://doi.org/10.31004/cendekia.v5i1.538

Nuriansyah, F. (2020). Efektifitas penggunaan media online dalam meningkatkan hasil belajar pada 
mahasiswa pendidikan ekonomi saat awal pandemi Covid-19. Jurnal Pendidikan Ekonomi Indonesia, 1(2). https://ejournal.upi.edu/index.php/JPEI/article/view/28346

Pertiwi, I., \& Marsigit, M. (2017). Implementasi pendidikan karakter dalam pembelajaran matematika

SMP di Kota Yogyakarta. Jurnal Riset Pendidikan Matematika, 4(2), 153. https://doi.org/10.21831/jrpm.v4i2.11241

Pujiastutik, H. (2019). Efektivitas penggunaan media pembelajaran e-learning berbasis web pada mata kuliah Belajar Pembelajaran I terhadap hasil belajar mahasiswa. Jurnal Teladan: Jurnal Ilmu Pendidikan Dan Pembelajaran, 25-36. http://journal.unirow.ac.id/index.php/teladan/article/view/46

Purwanto, N. (2010). Psikologi Pendidikan. PT Remaja Rosdakarya.

Saragih, O., Sebayang, F. A. A., Sinaga, A. B., \& Ridlo, M. R. (2020). Persepsi Mahasiswa terhadap Pembelajaran Daring selama Pandemi Covid-19. Tarbiyah Wa Ta'lim: Jurnal Penelitian Pendidikan Dan Pembelajaran, 7(3), 178-191. https://doi.org/10.21093/twt.v7i3.2624

Setyono, E. Y. (2017). Pengaruh penggunaan media jejaring sosial edmodo terhadap hasil belajar mahasiswa pada topik pembuatan kurva-s menggunakan Microsoft Excell. SOSHUM: Jurnal Sosial Dan Humaniora, 5(1), 42. https://ojs.pnb.ac.id/index.php/SOSHUM/article/view/226

Siregar, S. (2010). Statistika deskriptif untuk penelitian. Rajawali Pers.

Sugianto, L., \& Ilyas, M. (2020). Peningkatan Hasil Belajar Matematika melalui Pengembangan Perangkat Pembelajaran Berbasis Masalah Terintegrasi Kecerdasan Emosional dan Karakter. AlKhwarizmi: Jurnal Pendidikan Matematika Dan Ilmu Pengetahuan Alam, 8(1), 61-76. https://doi.org/10.24256/jpmipa.v8i1.984

Suripah, S., \& Retnawati, H. (2019). Investigating Students' Mathematical Creative Thinking Skill Based On Academic Level And Gender. International Journal of Scientific \&Technology Research, 8(8, Agustus 2019), 227-231. https://www.ijstr.org/final-print/aug2019/InvestigatingStudents-Mathematical-Creative-Thinking-Skill-Based-On-Academic-Level-And-Gender.pdf

Suryani, E. S., \& Andriani, S. (2020). Evaluasi Formatif Mahasiswa Terhadap Karakteristik Dan Keterampilan Mengajar Dosen Berkaitan Dengan Prestasi Belajar Matematika Di Jurusan Pendidikan Matematika Fkip Universitas Suryakancana (Unsur) Cianjur. Pasundan Journal of Mathematics Education Jurnal Pendidikan Matematika, 2(1). https://journal.unpas.ac.id/index.php/pjme/article/view/2458

Susanti, W. D., \& Suripah, S. (2021). The Effectiveness of Website as a Mathematics Learning Media During the Online Learning Period. Edumatica: Jurnal Pendidikan Matematika, 11(01), 73-83. https://doi.org/10.22437/edumatica.v11i01.12225

Sutisna, A. (2016). Pengembangan model pembelajaran blended learning pada pendidikan kesetaraan program paket c dalam meningkatkan kemandirian belajar. JTP-Jurnal Teknologi Pendidikan, 18(3), 156-168. https://doi.org/10.21009/jtp.v18i3.5373

Syaparuddin, S., \& Elihami, E. (2019). Peningkatan Motivasi Belajar Siswa Melalui Video pada 
Pembelajaran PKn di Sekolah Paket C. Jurnal Edukasi Nonformal, 1(1), 187-200. https://ummaspul.e-journal.id/JENFOL/article/view/318/149

Ulya, K., \& Hayati, Z. (2020). Perkembangan Rasa Ingin Tahu Mahasiswa melalui Pengintegrasian Nilai Islami dalam Pembelajaran Matematika. Jurnal Didaktik Matematika, 7(2), 171-189. https://doi.org/10.24815/jdm.v7i2.17374

Vhalery, R., Alfilail, S. N., Robbani, H., \& Hia, L. N. (2021). Persepsi Mahasiswa tentang Pembelajaran Online Google Classroom pada Minat dan Motivasi Belajar. Intelektium, 2(1), 28 36. https://doi.org/10.37010/int.v2i1.271

Wisada, P. D., \& Sudarma, I. K. (2019). Pengembangan media video pembelajaran berorientasi pendidikan karakter. Journal of Education Technology, 3(3), 140-146. https://doi.org/10.23887/jet.v3i3.21735

You, S., Dang, M., \& Lim, S. A. (2016). Effects of student perceptions of teachers' motivational behavior on reading, English, and mathematics achievement: The mediating role of domain specific self-efficacy and intrinsic motivation. Child \& Youth Care Forum, 45(2), 221-240. https://doi.org/10.1007/s10566-015-9326-x 